\title{
Pharmacokinetics of sulphadoxine and trimethoprim and tissue irritation caused by two sulphadoxine-trimethoprim containing products after subcutaneous administration in pre-ruminant calves
}

\author{
Liisa KAARTINEN $^{\mathrm{a} *}$, Marina Gips ${ }^{\mathrm{b}}$, Tapio LAURILA ${ }^{\mathrm{a}}$, Heidi HÄRTEL ${ }^{\mathrm{a}}$, \\ Stefan SoBACK ${ }^{b}$, Satu PYÖRÄLÄ ${ }^{\mathrm{a}}$ \\ ${ }^{a}$ University of Helsinki, Faculty of Veterinary Medicine, Department of Clinical Sciences, \\ FIN-04920 Saarentaus, Finland \\ ${ }^{\mathrm{b}}$ Kimron Veterinary Institute, National Residue Control Laboratory, PO Box 12, \\ 50250 Beit Dagan, Israel
}

(Received 25 November 1999; accepted 31 May 2000)

\begin{abstract}
The pharmacokinetics of sulphadoxine-trimethoprim was studied in 6 pre-ruminant calves using two different products. Product A, which contained $200 \mathrm{mg}$ sulphadoxine and $40 \mathrm{mg}$ trimethoprim per $\mathrm{mL}$, was administered intravenously or subcutaneously at a dosage of $25 \mathrm{mg}$ sulphadoxine and $5 \mathrm{mg}$ trimethoprim $\cdot \mathrm{kg}^{-1}$ bodyweight. Product $\mathrm{B}$, containing $62.5 \mathrm{mg}$ sulphadoxine and $12.5 \mathrm{mg}$ trimethoprim per $\mathrm{mL}$ plus lidocaine $\left(1 \mathrm{mg} \cdot \mathrm{mL}^{-1}\right)$, was given subcutaneously at the same dosage. After intravenous administration of product A the mean time of half-life of elimination phase $\left(\mathrm{t}_{1 / 2}\right)$ for sulphadoxine was $12.9 \mathrm{~h}$, steady-state volume of distribution $\left(\mathrm{V}_{\mathrm{d}(\mathrm{ss}}\right)$ was $0.44 \mathrm{~L} \cdot \mathrm{kg}^{-1}$ and clearance was $0.024 \mathrm{~L} \cdot \mathrm{kg}^{-1} \cdot \mathrm{h}^{-1}$. Respective values for trimethoprim were $1.9 \mathrm{~h}, 2.0 \mathrm{~L} \cdot \mathrm{kg}^{-1}$ and $0.9 \mathrm{~L} \cdot \mathrm{kg}^{-1} \cdot \mathrm{h}^{-1}$. After subcutaneous administration, the bioavailability of sulphadoxine was $96 \%$ and $98 \%$ and the time to reach a maximum concentration was 6.3 and $8.0 \mathrm{~h}$ for products $\mathrm{A}$ and $\mathrm{B}$, respectively. The $C_{\max }$ for trimethoprim was higher for product $A\left(0.49 \mu \mathrm{g} \cdot \mathrm{mL}^{-1}\right)$ than for product $\mathrm{B}\left(0.32 \mu \mathrm{g} \cdot \mathrm{mL}^{-1}\right)(p=0.014)$. Slow absorption from the injection site appeared to delay the elimination of trimethoprim after subcutaneous administration when compared to that after intravenous administration: apparent elimination $\mathrm{t}_{1 / 2}$ for trimethoprim after intravenous administration of product $\mathrm{A}$ was $1.9 \mathrm{~h}$ compared to $3.9 \mathrm{~h}$ and $3.6 \mathrm{~h}$ after subcutaneous administration of products $\mathrm{A}$ and $\mathrm{B}$, respectively. The difference between intravenous and subcutaneous administrations was statistically significant $(p<0.05)$. Also the mean residence time was significantly shorter $(p<0.05)$ after intravenous administration $(2.4 \mathrm{~h})$ than that after subcutaneous administration of product $\mathrm{A}(6.9 \mathrm{~h})$ and $\mathrm{B}(7.1 \mathrm{~h})$. The bioavailability of trimethoprim was lower than that of sulphadoxine: $76 \%$ and $74 \%$ for products $\mathrm{A}$ and
\end{abstract}

* Correspondence and reprints. Present address: Liisa Kaartinen, National Agency for Medicines, PO Box 55, FIN-00301 Helsinki, Finland.

Tel.: (358) 94733 4284; fax (358) 94733 4355; e-mail: liisa.kaartinen@ nam.fi 
B, respectively. All 6 calves showed pain after subcutaneous administration of product A and the injection sites were warm and showed soft oedematous reactions $5-8 \mathrm{~cm}$ in diameter. Three of the calves also showed some pain after subcutaneous administration of product $B$; the local reactions were less severe. A marked increase was seen in creatine kinase activity after subcutaneous administration of both products. Product A caused a more pronounced increase but the difference was not statistically significant. We suggest $30 \mathrm{mg} \cdot \mathrm{kg}^{-1}$ at 24 -h intervals or alternatively $15 \mathrm{mg} \cdot \mathrm{kg}^{-1}$ at 12 -h intervals as the minimum dosage of sulphadoxine-trimethoprim combination for pre-ruminant calves. Extravascular routes of administration should be avoided due to marked tissue irritation at the injection site.

potentiated sulphonamide / creatine kinase / bovine / calf

Résumé - Pharmacocinétique de la sulphadoxine et de la triméthoprime et irritation des tissus causée par deux produits contenant de la sulphadoxine et de la triméthoprime après une administration sous-cutanée chez des veaux préruminants. La pharmacocinétique de la sulphadoxinetriméthoprime a été étudiée chez six veaux préruminants en utilisant deux produits différents. Le produit A qui contenait $200 \mathrm{mg} \cdot \mathrm{mL}^{-1}$ de sulphadoxine et $40 \mathrm{mg} \cdot \mathrm{mL}^{-1}$ de triméthoprime a été administré par voie intraveineuse (i.v.) ou sous-cutanée (s.c.) à un dosage de $25 \mathrm{mg}$ de sulphadoxine et $5 \mathrm{mg}$ de triméthoprime $\cdot \mathrm{kg}^{-1}$ de poids vif. Le produit B contenant $62,5 \mathrm{mg} \cdot \mathrm{mL}^{-1}$ de sulphadoxine et $12,5 \mathrm{mg} \cdot \mathrm{mL}^{-1}$ de triméthoprime et $1 \mathrm{mg} \cdot \mathrm{mL}^{-1}$ de lidocaïne, a été donné au même dosage par voie souscutanée. Après administration i.v. du produit $A$, le temps de demi-vie d'élimination $\left(t_{1 / 2}\right)$ pour la sulphadoxine était de $12,9 \mathrm{~h}$, le volume de distribution à l'équilibre était de $0,44 \mathrm{~L} \mathrm{~kg}^{-1}$ et la clairance de $0,024 \mathrm{~L} \cdot \mathrm{kg}^{-1} \cdot \mathrm{h}^{-1}$. Les valeurs respectives pour la triméthoprime étaient de $1,9 \mathrm{~h}, 2,0 \mathrm{~L} \cdot \mathrm{kg}^{-1}$ et $0,9 \mathrm{~L} \cdot \mathrm{kg}^{-1} \cdot \mathrm{h}^{-1}$. Après administration s.c., la biodisponibilité de la sulphadoxine était respectivement de $96 \%$ et de $98 \%$ et le temps nécessaire pour atteindre une concentration maximale était respectivement 6,3 et $8,0 \mathrm{~h}$ pour les produits $\mathrm{A}$ et $\mathrm{B}$. $\mathrm{La}_{\max }$ de la triméthoprime était plus élevée pour le produit $\mathrm{A}\left(0,49 \mu \mathrm{g} \cdot \mathrm{mL}^{-1}\right)$ que pour le produit $\mathrm{B}\left(0,32 \mu \mathrm{g} \cdot \mathrm{mL}^{-1}\right)$. A cause de la lente absorption au niveau de la zone d'injection, l'élimination de la triméthoprime a été plus lente après administration s.c. qu'après l'administration i.v.: le $\mathrm{t}_{1 / 2}$ pour la triméthoprime après l'administration i.v. du produit A était de $1,9 \mathrm{~h}$ tandis qu'il était de 3,9 et de $3,6 \mathrm{~h}$ après l'administration s.c. des produits A et $\mathrm{B}$. La différence entre l'administration i.v. et l'administration s.c. était statistiquement significative $(p<0,05)$. Aussi le temps moyen de résidence après l'administration i.v. $(2,4 \mathrm{~h})$ était significativement plus court $(p<0,05)$ que celui constaté après l'administration s.c des produits $\mathrm{A}(6,9 \mathrm{~h})$ et $\mathrm{B}(7,1 \mathrm{~h})$. La biodisponibilité de la triméthoprime était plus basse que celle de la sulphadoxine: respectivement $76 \%$ et $74 \%$ pour les produits A et B. Les six veaux ont montré de la douleur après l'administration s.c. du produit $\mathrm{A}$ et les zones d'injection étaient chauds et présentaient des réactions oedémateuses souples de $5-8 \mathrm{~cm}$ de diamètre. Trois veaux ont également montré une légère douleur après l'administration du produit B; les réactions locales ont été moins sévères. Une augmentation notable de l'activité de la créatine kinase a été notée après l'administration s.c. des deux produits. Le produit A a causé une augmentation plus prononcée mais la différence n'était pas statistiquement significative. Nous proposons $30 \mathrm{mg} \cdot \mathrm{kg}^{-1}$ toutes les $24 \mathrm{~h}$ ou alternativement $15 \mathrm{mg} \cdot \mathrm{kg}^{-1}$ toutes les $12 \mathrm{~h}$ comme dosage minimum de la combinaison sulphadoxine-triméthoprime pour les veaux préruminants. Le produit devrait être injecté par voie intraveineuse pour éviter l'irritation du tissu dans la zone d'injection.

sulphonamide potentialisée / créatine kinase / bovin / veau

\section{INTRODUCTION}

Sulphonamides in combination with trimethoprim are commonly used for broad spectrum antimicrobial therapy in veterinary medicine. Although widespread resistance limits their use in ruminants the combination is still useful in the treatment of gastrointestinal and respiratory infections in calves, including neonatal colibacillosis [18].

Pharmacokinetic properties of different sulphonamides vary in cattle [13]. It is also known that the pharmaceutical formulation of the product may affect the pharmacokinetics of active substances as well as the 
tissue irritation caused by the product [11]. Pharmacokinetic behaviour of sulphonamides and trimethoprim differ from each other due to their chemical characteristics: sulphonamides act as weak acids while trimethoprim is a weak base, they thus concentrate at different locations in the body.

The aim of this study was to investigate the pharmacokinetics of sulphadoxine and trimethoprim using two different commercial products after intravenous (i.v.) and subcutaneous (s.c.) administration. Subcutaneous administration was selected since injection by this route is a common practice when treating young calves. Secondly, we assessed tissue irritation caused by these products after s.c. administration by clinical signs and by measuring creatine kinase (CK) activity.

\section{MATERIALS AND METHODS}

\subsection{Experimental design}

Six Finnish Ayrshire calves between 2 and 6 weeks of age were used in this crossover study (Tab. I). They weighed between 41 and $63 \mathrm{~kg}$ during the experiment. The

Table I. Study design. Product A was Borgal vet $\left(200 \mathrm{mg} \cdot \mathrm{mL}^{-1}\right.$ sulphadoxine and $40 \mathrm{mg} \cdot \mathrm{mL}^{-1}$ trimethoprim, Hoechst Roussel vet, Wiesbaden, Germany) and product B was Borgal mite vet (62.5 mg sulphadoxine $\cdot \mathrm{mL}^{-1}, 12.5 \mathrm{mg}$ trimethoprim $\cdot \mathrm{mL}^{-1}$ and lidocaine $\mathrm{HCl} 1 \mathrm{mg} \cdot \mathrm{mL}^{-1}$, Hoechst Roussel vet). Sulphadoxine and trimethoprim were administered at a dosage of $25 \mathrm{mg} \cdot \mathrm{kg}^{-1} \mathrm{BW}$ and $5 \mathrm{mg} \cdot \mathrm{kg}^{-1} \mathrm{BW}$, respectively.

\begin{tabular}{lccc}
\hline & \multicolumn{3}{c}{ Phase of the study } \\
\cline { 2 - 4 } Number of the calf & I & II & III \\
\hline $1 ; 4$ & A i.v. & A s.c. & B s.c. \\
$2 ; 5$ & B s.c. & A i.v. & A s.c. \\
$3 ; 6$ & A s.c. & B s.c. & A i.v. \\
\hline
\end{tabular}

A: Product A.

B: Product B. calves were given colostrum for the first two days and then fed whole milk three times a day. After 5 days, they were fed with a commercial milk replacer. They had free access to water and good quality hay during the experimental period. Each calf received a sulphadoxine-trimethoprim combination at a dosage of $30 \mathrm{mg} \cdot \mathrm{kg}^{-1}(25+$ $5 \mathrm{mg}$ ). Product A (Borgal ${ }^{\circledR}$ vet, $200 \mathrm{mg}$ sulphadoxine $\cdot \mathrm{mL}^{-1}$ and $40 \mathrm{mg}$ trimethoprim $\cdot \mathrm{mL}^{-1}$, Hoechst Roussel vet, Wiesbaden, Germany) was administered intravenously and subcutaneously. Product B (Borgal ${ }^{\circledR}$ mite vet, $62.5 \mathrm{mg}$ sulphadoxine $\cdot \mathrm{mL}^{-1}, 12.5 \mathrm{mg}$ trimethoprim $\cdot \mathrm{mL}^{-1}$ and lidocaine $\mathrm{HCl} 1 \mathrm{mg} \cdot \mathrm{mL}^{-1}$, Hoechst Roussel vet) was administered s.c. using the same dose. The subcutaneous injection was given on the lateral rib area behind the elbow. As the maximum volume in all cases was less than $25 \mathrm{ml}$ the s.c. injection was given at single site. Contralateral site was used for the second s.c. administration. The washout period between the administrations was one week. Serial blood samples were collected at 2, 8, 15 and $30 \mathrm{~min}$, and at 1, 2, 4, $8,12,24,36$ and $48 \mathrm{~h}$. After clotting, serum was separated and stored at $-20{ }^{\circ} \mathrm{C}$ until analysed.

\subsection{Tissue irritation}

Reactions at the site of s.c. injection were monitored clinically and by determination of serum creatine kinase (CK) activity in order to assess damage to the superficial muscles due to subcutaneous injection. Clinical reactions, such as swelling or tenderness at the injection sites, were recorded by inspection and palpation during the experimental period by the same person, who was unaware of the given treatment. Clinical findings (pain, skin temperature, oedema) were recorded using a scoring system where 0 equalled to no reaction and 3 equalled to severe reaction. CK activity was assessed by routine methods [1] and areas under CK activity time curves $\left(\mathrm{AUC}_{\mathrm{CK}(0-48 \mathrm{~h})}\right.$ ) were calculated for statistical comparison. 


\subsection{Analysis of sulphadoxine and trimethoprim}

The sulphadoxine and trimethoprim assay was performed in the Kimron Veterinary Institute using reversed phase high-performance liquid chromatography (HPLC) with a diode array detector (Hewlett-Packard 1090, Avondale, PA, USA). A Hypersil C18 BDS column $(3 \mu, 100 \times 4.6 \mathrm{~mm}$ Shandon, Cheshire, UK) was used. The mobile phase consisted of $0.05 \mathrm{M}$ sodium acetate (Sigma, St. Louis, MO, USA) at pH 3.0, acetonitrile (Chromasolv, Riedel and DeHaen, Seelze, Germany) and methanol (Chromasolv) at a ratio of $80: 5: 15$ using a flow rate of $1.0 \mathrm{~mL} \cdot \mathrm{min}^{-1}$. The detector wave length was adjusted to $245 \mathrm{~nm}$ from 0 to $5 \mathrm{~min}$ for trimethoprim and to $265 \mathrm{~nm}$ from $5 \mathrm{~min}$ to the end of the run for sulphadoxine. The injection volume was $20 \mu \mathrm{L}$. Standard curves were prepared in antibiotic-free calf serum and processed according to the same procedure as the serum samples. The limit of quantification was $0.05 \mu \mathrm{g} \cdot \mathrm{mL}^{-1}$ for trimethoprim and $0.1 \mu \mathrm{g} \cdot \mathrm{mL}^{-1}$ for sulphadoxine. The standard curve was linear within the range from 0.05 to $10 \mu \mathrm{g} \cdot \mathrm{mL}^{-1}$ for trimethoprim $\left(r^{2} 0.999\right)$ and from 0.1 to $100 \mu \mathrm{g} \cdot \mathrm{mL}^{-1}$ for sulphadoxine $\left(r^{2} 0.999\right)$. Precision analysis showed that the inter-day coefficient of variation among 4 replicates was $4 \%$ at $0.05 \mu \mathrm{g} \cdot \mathrm{mL}^{-1}, 8 \%$ at $1.0 \mu \mathrm{g} \cdot \mathrm{mL}^{-1}$ and $2 \%$ at $10 \mu \mathrm{g} \cdot \mathrm{mL}^{-1}$ for trimethoprim. The respective figures for sulphadoxine were $6 \%, 6 \%$ and $3 \%$ at concentrations of $1 \mu \mathrm{g} \cdot \mathrm{mL}^{-1}, 5 \mu \mathrm{g} \cdot \mathrm{mL}^{-1}$ and $10 \mu \mathrm{g} \cdot \mathrm{mL}^{-1}$, respectively. Recoveries from serum samples were more than $60 \%$. The results were corrected for recovery using internal standard (sulfisoxazole).

For the assay, an aliquot of $0.9 \mathrm{~mL}$ of the sample was extracted twice with $6 \mathrm{~mL}$ ethyl acetate (Frutarom, Haifa, Israel), evaporated to dryness under a gentle stream of nitrogen and reconstituted in $100 \mu \mathrm{L}$ acetate buffer (0.05 M, pH 3.0) before injecting the sample into an analyser. Trimethoprim and sulphadoxine standards were prepared in antibiotic-free calf serum and processed according to the same procedure as that used with serum samples.

\subsection{Data analysis}

The drug concentration-time data in serum were analysed with software based on the statistical moment theory [27]. When all treatment effects were compared statistical analysis of pharmacokinetic parameters was carried out using the analysis of variance for $3 \times 3$ cross-over design. Subject effects, period effects, direct treatment effects and carry-over effects were tested sequentially and if there were no evidence of different carry-over effects they were excluded and reduced model was used to test treatment effects [9]. Tukey's HSD test was used in multiple comparisons $(\alpha<0.05)$. Pharmacokinetic parameters, which were relevant only for subcutaneous administration of products $\mathrm{A}$ and $\mathrm{B}$, were analysed as $2 \times 2$ cross-over designs.

\section{RESULTS}

Mean concentration-time curves for sulphadoxine and trimethoprim are shown in Figure 1. Pharmacokinetic parameters are shown in Tables II and III. For determination of the slope of elimination phases, 3-6 time points were used. For trimethoprim after s.c. administration of both product A and B only 2 time points could be used for 3 calves, which lead to rather large proportion of extrapolated AUC $\left(\mathrm{AUC}_{(0-\mathrm{t})} /\right.$ $\left.\mathrm{AUC}_{(0 \text {-infinitive })} 61-84 \%\right)$. The respective figure in other cases was $88-98 \%$.

No evidence of any differences in the first-order carry-over effects was found in statistical analysis of the pharmacokinetic parameters for sulphadoxine and trimethoprim. The product or route of administration did not cause any statistically significant differences in the pharmacokinetic parameters of sulphadoxine. After s.c. administration, bioavailability was $96 \%$ and $98 \%$ for 

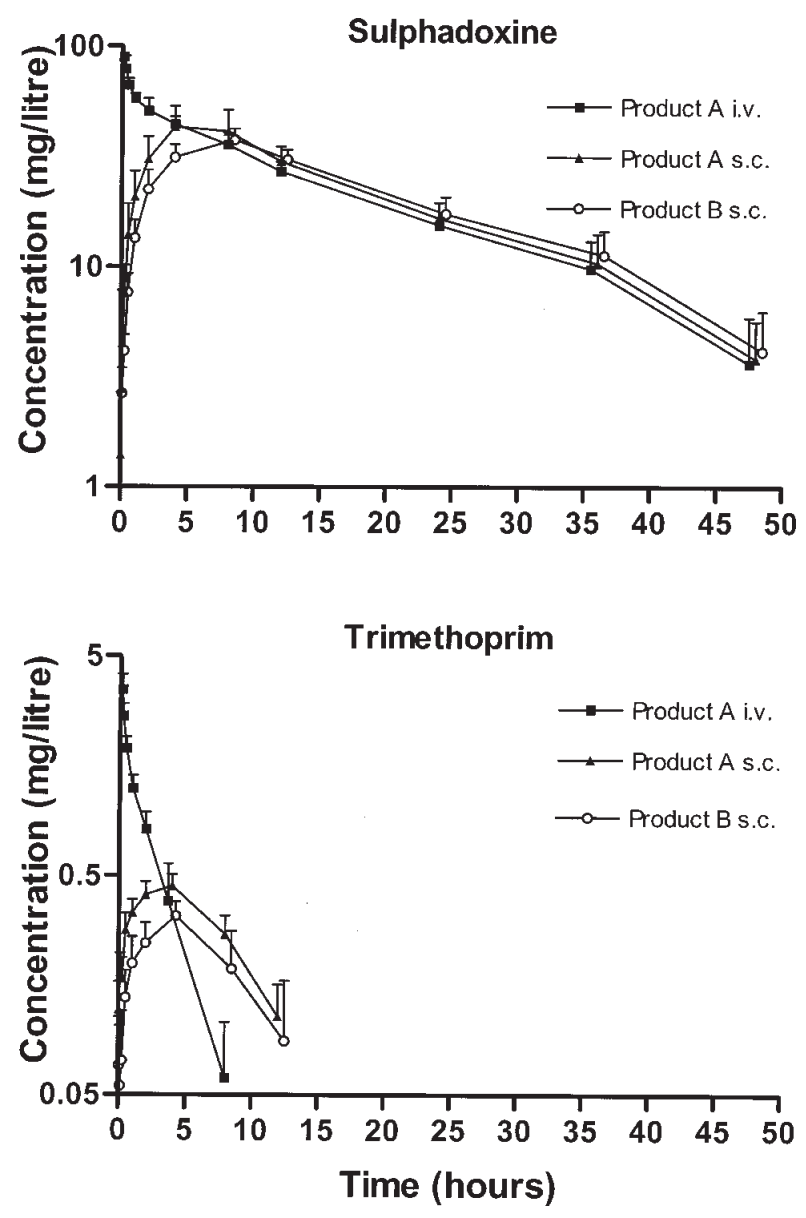

Figure 1. Mean concentration-time profile of sulphadoxine (upper panel) and trimethoprim (lower panel) in serum after intravenous administration of product A, subcutaneous administration of product A and subcutaneous administration of product B. Mean of 6 calves for each administration. Standard deviations are indicated. Each calf received $25 \mathrm{mg} \cdot \mathrm{kg}^{-1}$ and $5 \mathrm{mg} \cdot \mathrm{kg}^{-1} \mathrm{BW}$ sulphadoxine and trimethoprim, respectively.

products $\mathrm{A}$ and $\mathrm{B}$, respectively. The time to reach a maximum concentration for sulphadoxine was 6.3 and $8.0 \mathrm{~h}$ after s.c. administration of products A and B, respectively.

In case of trimethoprim, treatment effects were significant for $\mathrm{AUC}_{(0 \text {-infinitive) }}$, MRT and elimination $\mathrm{t}_{1 / 2}$. The apparent elimination $t_{1 / 2}$ and mean residence time (MRT) of trimethoprim were significantly longer after s.c. administration than elimination $\mathrm{t}_{1 / 2}$ after i.v. administration $(p<0.05)$ (table III). The individuals were a cause of variation because subject effects were significant for AUC $_{(0 \text {-infinitive })}$ and MRT $(p<0.05)$. Significant difference was noted in the pharmacokinetics of trimethoprim after s.c. administration of products $\mathrm{A}$ and $\mathrm{B}$ : the maximum concentration $\left(C_{\max }\right)$ was higher for product $\mathrm{A}\left(0.49 \mu \mathrm{g} \cdot \mathrm{mL}^{-1}\right)$ than for product B $\left(0.34 \mu \mathrm{g} \cdot \mathrm{mL}^{-1} ; p=0.014\right)$. The bioavailabilities were $76 \%$ and $74 \%$ for 
Table II. Pharmacokinetic parameters of sulphadoxine $\left(25 \mathrm{mg} \cdot \mathrm{kg}^{-1} \mathrm{BW}, n=6\right.$ calves per group). Mean \pm standard deviation (range). No statistically significant differences were found.

\begin{tabular}{|c|c|c|c|}
\hline $\begin{array}{l}\text { Pharmacokinetic } \\
\text { parameter }\end{array}$ & $\begin{array}{c}\text { Product A } \\
\text { Intravenous route }\end{array}$ & $\begin{array}{c}\text { Product A } \\
\text { Subcutaneous route }\end{array}$ & $\begin{array}{c}\text { Product B } \\
\text { Subcutaneous route }\end{array}$ \\
\hline $\operatorname{AUC}_{(0-\infty)}\left(\mathrm{mg} \cdot \mathrm{h} \cdot \mathrm{L}^{-1}\right)$ & $\begin{array}{c}1085 \pm 147 \\
(857-1252)\end{array}$ & $\begin{array}{c}1037 \pm 131 \\
(843-1194)\end{array}$ & $\begin{array}{c}1015 \pm 148 \\
(814-1194)\end{array}$ \\
\hline MRT (h) & $\begin{array}{l}18.4 \pm 4.2 \\
(12.6-23.1)\end{array}$ & $\begin{array}{l}19.8 \pm 3.9 \\
(15.5-24.7)\end{array}$ & $\begin{array}{l}22.1 \pm 5.1 \\
(17.0-28.7)\end{array}$ \\
\hline $\mathrm{t}_{1 / 2}(\mathrm{~h})$ & $\begin{array}{c}12.9 \pm 3.7 \\
(8.4-17.0)\end{array}$ & $\begin{array}{l}12.5 \pm 2.2 \\
(10.0-15.2)\end{array}$ & $\begin{array}{c}13.2 \pm 3.6 \\
(9.5-17.8)\end{array}$ \\
\hline $\mathrm{V}_{\mathrm{d}(\mathrm{ss})}\left(\mathrm{L} \cdot \mathrm{kg}^{-1}\right)$ & $\begin{array}{l}0.44 \pm 0.05 \\
(0.38-0.49)\end{array}$ & - & - \\
\hline $\mathrm{Cl}\left(\mathrm{L} \cdot \mathrm{kg}^{-1} \cdot \mathrm{h}^{-1}\right)$ & $\begin{array}{c}0.024 \pm 0.004 \\
(0.021-0.030)\end{array}$ & - & - \\
\hline MAT (h) & - & $\begin{array}{l}2.7 \pm 3.9 \\
(0.0-9.9)\end{array}$ & $\begin{array}{l}3.4 \pm 3.5 \\
(0.0-9.3)\end{array}$ \\
\hline $\mathrm{C}_{\max }\left(\mathrm{mg} \cdot \mathrm{L}^{-1}\right)$ & - & $\begin{array}{l}45.2 \pm 9.0 \\
(36.0-60.0)\end{array}$ & $\begin{array}{l}37.1 \pm 4.6 \\
(31.0-43.0)\end{array}$ \\
\hline $\mathrm{T}_{\max }(\mathrm{h})$ & & $\begin{array}{l}6.3 \pm 2.0 \\
(4.0-8.0)\end{array}$ & $\begin{array}{l}8.0 \\
(-)\end{array}$ \\
\hline $\mathrm{F}(\%)$ & - & $\begin{array}{l}96 \pm 13 \\
(82-116)\end{array}$ & $\begin{array}{l}98 \pm 13 \\
(74-110)\end{array}$ \\
\hline
\end{tabular}

$\operatorname{AUC}_{(0-\infty)}$ : area under the concentration-time curve; MRT: mean residence time; $t_{1 / 2}$ : elimination half-life; $\mathrm{V}_{\mathrm{d}(\mathrm{ss})}$ : volume of distribution at steady-state; $\mathrm{Cl}$ : clearance; MAT: mean absorption time; $\mathrm{C}_{\max }$ : maximum concentration; $\mathrm{T}_{\max }$ : time when maximum concentration is reached; $\mathrm{F}$ : bioavailability.

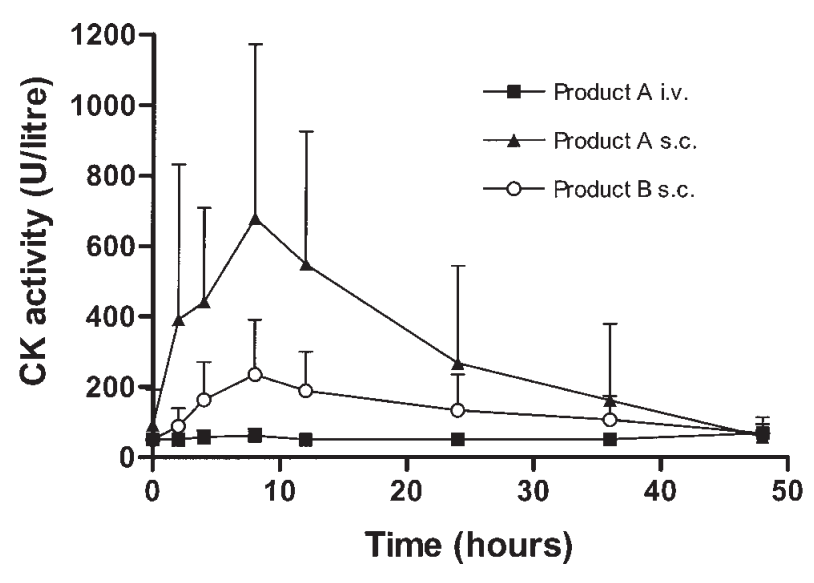

Figure 2. Creatine kinase activity in serum after intravenous administration of product A, subcutaneous administration of product $\mathrm{A}$ and subcutaneous administration of product $\mathrm{B}$. Mean of 6 calves for each route of administration. Standard deviations are indicated. Each calf received $25 \mathrm{mg} \cdot \mathrm{kg}^{-1}$ and $5 \mathrm{mg} \cdot \mathrm{kg}^{-1} \mathrm{BW}$ sulphadoxine and trimethoprim, respectively. 
Table III. Pharmacokinetic parameters of trimethoprim $\left(5 \mathrm{mg} \cdot \mathrm{kg}^{-1} \mathrm{BW}, n=6\right.$ calves per group). Mean \pm standard deviation (range). Statistical differences in each parameter have been indicated using different letters. In each row means with different letters are statistically significantly different from each other.

\begin{tabular}{|c|c|c|c|}
\hline $\begin{array}{l}\text { Pharmacokinetic } \\
\text { parameter }\end{array}$ & $\begin{array}{c}\text { Product A } \\
\text { Intravenous route }\end{array}$ & $\begin{array}{c}\text { Product A } \\
\text { Subcutaneous route }\end{array}$ & $\begin{array}{c}\text { Product B } \\
\text { Subcutaneous route }\end{array}$ \\
\hline $\operatorname{AUC}_{(0-\infty)}\left(\mathrm{mg} \cdot \mathrm{h} \cdot \mathrm{L}^{-1}\right)$ & $\begin{array}{r}5.9^{\mathrm{a}} \pm 1.4 \\
(4.5-7.7)\end{array}$ & $\begin{array}{r}4.4^{\mathrm{b}} \pm 1.7 \\
(2.9-7.5)\end{array}$ & $\begin{array}{l}3.1^{\mathrm{c}} \pm 1.2 \\
(2.0-5.2)\end{array}$ \\
\hline MRT (h) & $\begin{array}{r}2.4^{\mathrm{a}} \pm 1.2 \\
(1.4-4.7)\end{array}$ & $\begin{array}{l}6.9^{\mathrm{b}} \pm 2.1 \\
(4.4-10.6)\end{array}$ & $\begin{array}{l}7.1^{\mathrm{b}} \pm 2.5 \\
(4.0-11.3)\end{array}$ \\
\hline $\mathrm{t}_{1 / 2}(\mathrm{~h})$ & $\begin{array}{r}1.9^{\mathrm{a}} \pm 0.9 \\
(1.1-3.6)\end{array}$ & $\begin{array}{r}3.9^{\mathrm{b}} \pm 1.3 \\
(2.7-5.7)\end{array}$ & $\begin{array}{c}3.6^{\mathrm{b}} \pm 1.6 \\
(1.8-6.1)\end{array}$ \\
\hline $\mathrm{V}_{\mathrm{d}(\mathrm{ss})}\left(\mathrm{L} \cdot \mathrm{kg}^{-1}\right)$ & $\begin{array}{l}2.0 \pm 0.6 \\
(1.5-3.1)\end{array}$ & - & - \\
\hline 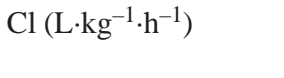 & $\begin{array}{l}0.9 \pm 0.2 \\
(0.7-1.1)\end{array}$ & - & - \\
\hline MAT (h) & - & $\begin{array}{l}1.6 \pm 1.6 \\
(0.0-4.1)\end{array}$ & $\begin{array}{l}1.4 \pm 1.3 \\
(0.0-3.5)\end{array}$ \\
\hline $\mathrm{C}_{\max }\left(\mathrm{mg} \cdot \mathrm{L}^{-1}\right)$ & - & $\begin{array}{r}0.49^{\mathrm{a}} \pm 0.12 \\
(0.32-0.67)\end{array}$ & $\begin{array}{r}0.34^{\mathrm{b}} \pm 0.03 \\
(0.31-0.38)\end{array}$ \\
\hline $\mathrm{T}_{\max }(\mathrm{h})$ & - & $\begin{array}{l}3.3 \pm 1.0 \\
(2.0-4.0)\end{array}$ & $\begin{array}{l}4.0 \pm 1.3 \\
(2.0-6.0)\end{array}$ \\
\hline $\mathrm{F}(\%)$ & - & $\begin{array}{l}76 \pm 26 \\
(47-114)\end{array}$ & $\begin{array}{l}74 \pm 25 \\
(38-104)\end{array}$ \\
\hline
\end{tabular}

$\mathrm{AUC}_{(0-\infty)}$ : area under the concentration-time curve; MRT: mean residence time; $\mathrm{t}_{1 / 2}$ : elimination half-life; $\mathrm{V}_{\mathrm{d}(\mathrm{ss})}$ : volume of distribution at steady-state; $\mathrm{Cl}$ : clearance; MAT: mean absorption time; $\mathrm{C}_{\max }$ : maximum concentration; $\mathrm{T}_{\max }$ : time when maximum concentration is reached; $\mathrm{F}$ : bioavailability.

products $\mathrm{A}$ and $\mathrm{B}$ respectively, compared to i.v. administration of product A.

All 6 calves showed signs of local pain after s.c. administration of product A (mean score 1.8). The injection sites were warm and had soft oedematous reactions $5-8 \mathrm{~cm}$ in diameter. Three of the calves also showed some pain after s.c. administration of product B (mean score 0.7). The difference was not statistically significant. The local reactions were somewhat smaller, from 3-6 cm in diameter after administration of product B. Both skin temperature scores and oedema scores were higher for product A but again the differences were not statistically significant. Subcutaneous administration of the products caused a clear increase in CK activity when compared with intravenous administration (Fig. 2). Tissue irritation caused by product $\mathrm{A}$ was greater than that of product $\mathrm{B}$ but the difference in $\mathrm{CK}$ activity when expressed as area under CK activity - time curves was not significant. The mean AUC for product A was 14703 $\mathrm{U} \cdot \mathrm{L}^{-1} \cdot \mathrm{h}^{-1}$ (range 3799-33 943) and for product B $6408 \mathrm{U} \cdot \mathrm{L}^{-1} \cdot \mathrm{h}^{-1}$ (range 2602-11 792), respectively.

\section{DISCUSSION}

We chose not to use neonatal calves in order to avoid age bias; it has been shown that the ability to metabolise trimethoprim develops quite early in cattle. At one week of age trimethoprim elimination is already markedly faster than at one day of age [8, 22]. At six weeks of age the elimination half-life of trimethoprim is close to that of adult cattle and no trimethoprim can be detected in serum after s.c. administration of $2.5 \mathrm{mg}$ trimethoprim $\cdot \mathrm{kg}^{-1}$ [8]. In addition, 
we used a cross-over design in order to further eliminate possible age effects. Calves were between 2 and 6 weeks of age during the study. The design was unbalanced thus it was not possible to separate accurately treatment and carry-over effects. The treatment effects were considered more pronounced as one-week wash-out period wash was likely to eliminate most of the carryover effects. The parameters after subcutaneous administration were analysed using $2 \times 2$ cross-over design assuming that intravenous administration of product $\mathrm{A}$ did not have confounding effect.

Studies of pharmacokinetics of the sulphadoxine-trimethoprim in lactating cattle $[7,13]$ have reported elimination half-lives of $11 \mathrm{~h}$ and about $13 \mathrm{~h}$ for sulphadoxine after i.v. administration. The respective figures for trimethoprim were $0.8-1.7 \mathrm{~h}$ and 1-2 h. In a study of pharmacokinetic behaviour of 11 sulphonamides including intravenous administration of sulphadoxine in cows Nielsen et al. [14] reported a $t_{1 / 2}$ of $10.8 \mathrm{~h}$. These results are in the same range as those for the half-life of sulphadoxine $(12.9 \mathrm{~h})$ and trimethoprim $(1.9 \mathrm{~h})$ in our study. The only study about the pharmacokinetics of sulphadoxine and trimethoprim calves/young cattle that we are aware of was carried out on animals weighing about $190 \mathrm{~kg}$ [15]. In this study, $\mathrm{t}_{1 / 2}$ of $14 \mathrm{~h}$ and $2.5 \mathrm{~h}$ were reported for sulphadoxine and trimethoprim after i.v. administration, respectively. Pharmacokinetic properties of another sulphadiazine-trimethoprim combination were investigated in calves [8, 21, $22,26]$. Shoaf et al. [21] reported a $t_{1 / 2}$ of $2.1 \mathrm{~h}$ for trimethoprim after an i.v. administration of $5 \mathrm{mg}$ of active substances $\mathrm{kg}^{-1}$ to one-week old calves but no trimethoprim could be detected after subcutaneous administration of the same dose in calves between 7 and 13 weeks of age [22].

The only difference in the pharmacokinetics of trimethoprim after s.c. administration of these two pharmaceutical products was significantly higher $\mathrm{C}_{\max }$ of trimethoprim for product $\mathrm{A}$. We have shown earlier that after intramuscular or subcutaneous administration of a sulphadiazinetrimethoprim product, the absorption of trimethoprim was strongly delayed and resulted in an apparent elimination half-life of 21-25 h in lactating dairy cattle at a trimethoprim dosage of $8 \mathrm{mg} \cdot \mathrm{kg}^{-1}$ [10]. The dosage used in this study was only $5 \mathrm{mg} \cdot \mathrm{kg}^{-1}$ and different product was used. We were not able to show such a slow absorption although the apparent elimination half-life was somewhat longer after subcutaneous administration of both product $\mathrm{A}$ and $\mathrm{B}$. The sampling times in our study were not optimal for analysis of pharmacokinetics of trimethoprim after s.c. administration. However, our results indicated that the elimination $t_{1 / 2}$ of trimethoprim appeared to be longer after s.c. administration than that after i.v. administration indicating that absorption limited elimination (flip-flop phenomenon).

CK has been shown to be a reliable indicator of muscle damage caused by intramuscular (i.m.) injections of irritating drugs $[24,25]$. Becker et al. [3] reported that sulphadoxine-trimethoprim caused a marked increase of CK after s.c. administration: the increase was about $20 \%$ of that caused by i.m. administration. Muscle damage after s.c. injection of the more concentrated product A was considerable here as well and could be compared to that caused by i.m. injection of the same preparation [19]. All calves showed signs of pain after injection of this product. In the summary of product characteristics of this preparation, s.c. administration is indicated for all animal species, which can be questioned from the animal welfare point of view. The less concentrated preparation is not authorised for cattle ([4], Finnish data sheet for Borgal Mite vet. injection), but has been used offlabel for calves because it has been expected to be more tissue-friendly. The acute pain reaction and other clinical signs were less pronounced after administration of the product B although the overall tissue damage when measured by increased CK activity 
was not significantly less than that caused by product A. Diminished pain reaction after administration of product $B$ could be due to lidocaine because it has been shown that incorporation of lidocaine into cephalosporin injections masked the acute pain after administration but did not reduce muscle damage in the rat paw-lick model [6]. Based on tissue irritation data product $B$ should be favoured when sulphadoxine-trimetoprim is administered via extravenous route. Unfortunately due to lack of a maximum residue limit for lidocaine in cattle or swine the marketing authorisation of this product for food-producing species was withdrawn in Finland and in other EU member states by the end of 1999.

The dosage of an antimicrobial to treat infection depends on the infecting agent and its in vitro susceptibility to the drug used, as well as the target site and pharmacokinetic properties of the drug. Main indications for the combination sulphadoxinetrimethoprim are calf diarrhoea caused by Escherichia coli, salmonellosis, and respiratory infections $[18,20]$. In vitro breakpoint values for trimethoprim-sulphonamide combinations for bacteria isolated from animals were recently published [2]. A breakpoint equal to or less than $2 / 38$ (trimethoprim/sulphonamide; $\mu \mathrm{g} \cdot \mathrm{mL}^{-1}$ ) should be used for isolates from the urinary tract; for systemic diseases, isolates with MICs equal to or less than $0.5 / 9.5$ should be considered susceptible.

The dose regimens suggested for sulphonamide-trimethoprim combinations in the literature vary considerably. The normal dose level recommended by the manufacturer in data sheets of the products studied here is $15 \mathrm{mg} \cdot \mathrm{kg}^{-1}$ once a day for all animal species. According to another source [4] this dose can even be given on alternate days. On the contrary, a much higher dosage of $24 \mathrm{mg} \cdot \mathrm{kg}^{-1}$ at 12 -h intervals is advised as the usual dosage of sulphonamidetrimethoprim combination in animals [18]. If we consider the MIC value $0.5 / 9.5 \mu \mathrm{g} \cdot \mathrm{mL}^{-1}$ (trimethoprim/sulphonamide) to be the tar- get level in blood, the dosage of $30 \mathrm{mg}$ active substances $\cdot \mathrm{kg}^{-1}$ for all routes of administration at $24-\mathrm{h}$ intervals would be sufficient as regards the sulphonamide component. Unfortunately trimethoprim has a very short half-life in cattle, as also seen in this study, and maintaining bactericidal or even bacteriostatic plasma concentrations of the combination thus leads to impractical dosage intervals. However, a more infrequent dosage is partly compensated for by the high and prolonged concentration of trimethoprim in tissues compared with that in plasma $[12,16]$. It was also shown that an acute phase protein, $\alpha_{1}$-acid glycoprotein, which increases in diseases, can bind basic drugs such as trimethoprim [23] and thus change the pharmacokinetics of these drugs. The pharmacokinetics of trimethoprim may thus be more favourable in diseased animals. Furthermore, the range of concentrations of the sulphonamide-trimethoprim combination, which offers synergistic activity, is relatively large $[5,17]$. One study using an experimental salmonellosis model in calves showed that blood levels of trimethoprim were of little value as a predictor of efficacy [26]. Many antimicrobials have been used successfully in clinical conditions despite their less favourable pharmacokinetics [18], and ultimately the efficacy of antimicrobials must always be confirmed in clinical trials.

Based on this pharmacokinetics study, we suggest $30 \mathrm{mg} \cdot \mathrm{kg}^{-1}$ at 24 -h intervals or alternatively $15 \mathrm{mg} \cdot \mathrm{kg}^{-1}$ at $12-\mathrm{h}$ intervals as the minimum dosage of sulphadoxinetrimethoprim combination for pre-ruminant calves. Extravascular routes of administration should be avoided due to tissue irritation at the injection site.

\section{ACKNOWLEDGEMENTS}

We thank Satu Sankari, DVM, Ph.D., Central Laboratory of the Faculty of Veterinary Medicine (Helsinki) for the analysis of the CK activities and Arto Ketola, M.Sc. (Soc.) for statistical analysis. 


\section{REFERENCES}

[1] Anonymous, The Committee on Enzymes of the Scandinavian Society for Clinical Chemistry and Clinical Physiology: Recommended method for the determination of creatine kinase in blood, Scand. J. Clin. Lab. Invest. 36 (1976) 711-723.

[2] Anonymous, Performance standards for antimicrobial disk and dilution susceptibility tests for bacteria isolated from animals; approved standard, NCCLS Document M31-A, Pennsylvania, 1999.

[3] Becker W., Klatt P., Seeger K., Untersuchungen nach subkutaner und intramuskulörer Applikation von Borgal-Lösung $24 \%$ ad us. vet. beim Kalb, Tierärztl. Umsch. 42 (1987) 266-270.

[4] Bishop Y. (Ed.) The Veterinary Formulary, 4th ed., Pharmaceutical Press, Great Britain, 1998.

[5] Bushby S.R.M., Sulfonamide and trimethoprim combinations, J. Am. Vet. Med. Assoc. 176 (1980) 1049-1053.

[6] Comereski C.R., Williams P.D., Bregman C.L., Hottendorf G.H., Pain on injection and muscle irritation: a comparison of animal models for assessing parenteral antibiotics, Fundam. Appl. Toxicol. 6 (1986) 335-338.

[7] Davitiyananda D., Rasmussen F., Half-lives of sulphadoxine and trimethoprim after a single intravenous infusion in cows, Acta Vet. Scand. 15 (1974) 356-365

[8] Guard C.L., Schwark W.S., Friedman D.S., Blackshear P., Haluska M., Age-related alterations in trimethoprim-sulfadiazine disposition following oral or parenteral administration in calves, Can. J. Vet. Res. 50 (1986) 342-346.

[9] Jones B., Kenward M.G., Design and Analysis of Cross-Over Trials, Chapman and Hall, London, 1990.

[10] Kaartinen L., Löhönen K., Wiese B., Franklin A., Pyörälä S. Pharmacokinetics of sulphadiazinetrimethoprim in lactating dairy cows, Acta Vet. Scand. 40 (1999) 271-278.

[11] Lefèbvre H.P., Braun V., Laroute V., Toutain P.L., Evaluation and mechanisms of tolerance of locally administered drugs, J. Vet. Pharmacol. Ther. 20 (Suppl. 1) (1997) 320-322.

[12] Nielsen P., Rasmussen F., Concentrations of trimethoprim and sulphadoxine in tissues from goats and a cow, Acta Vet. Scand. 16 (1975) 405410 .

[13] Nielsen P., Rasmussen F., Half-life, apparent volume of distribution and protein-binding for some sulphonamides in cows, Res. Vet. Sci. 22 (1977) 205-208.

[14] Nielsen P., Romvary A., Rasmussen F., Sulphadoxine and trimethoprim in goats and cows: absorption fraction, half-lives and the degrading effect of the ruminal flora, J. Vet. Pharmacol. Ther. 1 (1978) 37-46.

[15] Pashov, D., Mutafchieva, R., Drumev, D., Koichev, K.B., Abramova, N., Pharmacokinetics, biological availability and tissue residues of a combination of sulfadoxine and trimethoprim injected into calves, Vet. Med. Nauki 21 (1984) 84-93.

[16] Piercy D.T.W., Distribution of trimethoprim/sulphadiazine in plasma, tissue and synovial fluids, Vet. Rec. 102 (1978) 523-524.

[17] Plumb D.C., Veterinary drug handbook, 2nd ed., Iowa State University Press, Ames, 1995.

[18] Prescott J.F., Baggot J.D. (Eds.), Antimicrobial Therapy in Veterinary Medicine, 2nd ed., Iowa State Univ. Press, Ames, 1993.

[19] Pyörälä S., Manner E., Kesti E., Sandholm M., Local tissue damage in cows after intramuscular injections of eight different antimicrobial agents, Brief communication, Acta Vet. Scand. 35 (1994) 107-110.

[20] Roussel A.J. Jr., Brumbaugh G.W., Treatment of diarrhea of neonatal calves, Vet. Clin. North Am. Food Anim. Pract. 7 (1991) 713-728.

[21] Shoaf S.E., Schwark W.S., Guard C.L., Schwartsman R.V., Pharmacokinetics of trimethoprim/sulfadiazine in neonatal calves: influence of synovitis, J. Vet. Pharmacol. Ther. 9 (1986) 446-454.

[22] Shoaf S.E., Schwark W.S., Guard C.L., The effect of age and diet on sulfadiazine/trimethoprim disposition following oral and subcutaneous administration to calves, J. Vet. Pharmacol. Ther. 10 (1987) 331-345

[23] Son D.S., Hariya S., Shimoda M., Kokue, E., Contribution of $\alpha_{1}$-acid glycoprotein to plasma protein binding of some basic antimicrobials in pigs, J. Vet. Pharmacol. Ther. 19 (1996) 170-183.

[24] Steiness E., Rasmussen F., Svendsen O., Nielsen P., A comparative study of serum creatine phosphokinase (CPK) activity in rabbits, pigs and humans after intramuscular injection of local damaging drugs, Acta Pharmacol. Toxicol. 42 (1978) 357-364.

[25] Toutain P.L., Lassourd V., Costes G., Alvinerie M., Bret L., Lefèbvre H.P., Braun J.P., A noninvasive and quantitative method for the study of tissue injury caused by intramuscular injection of drugs in horses, J. Vet. Pharmacol. Ther. 18 (1995) 226-235.

[26] White G., Piercy D.W.T., Gibbs H.A., Use of a calf salmonellosis model to evaluate the therapeutic properties of trimethoprim and sulphadiazine and their mutual potentiation in vivo, Res. Vet. Sci. 31 (1981) 27-31.

[27] Yamaoka K., Nakagawa T., Uno T., Statistical moments in pharmacokinetics, J. Pharmacokinet. Biopharm. 6 (1978) 547-558. 